POLITEKNIK NEGERI NUSA UTARA

\title{
PENGARUH PERENDAMAN DAN DURASINYA DALAM LARUTAN MADU TERHADAP MASKULINASASI LARVA Oreochromis niloticus
}

\author{
Effect of Immersion and Its Duration in Honneybee on Masculinization of Oreochromis \\ Niloticus Larvae's
}

\author{
Aprelia Martina Tomasoa, Deidy Azhari, Christian Andelsen Manansang, Ferly Feybe Dansole \\ Program Studi Teknologi Budidaya Ikan, Jurusan Perikanan dan Kebaharian, Politeknik Negeri Nusa Utara \\ Email: apriltomasoa@gmail.com
}

\begin{abstract}
Abstrak: Budidaya ikan nila monoseks jantan memiliki peranan penting dalam meningkatkan produksi ikan nila. Meskipun saat ini teknik maskulinisasi menggunakan hormon sintetik umum diterapkan namun cara ini berbahaya dari segi keamanan pangan dan konsumen karena sifat karsinogenik dan potensi akumulasi di alam dari hormon sintetik. Sebaliknya, bahan alami seperti madu yang menggandung Chrysin, yang telah diketahui sebagai aromatase inhibitor yang dapat menyebabkan maskulinisasi pada ikan dapat digunakan dalam teknik maskulinisasi. Meskipun demikian, sejauh ini pengaruh perendaman larva ikan nila dalam larutan madu terhadap maskulinisasi masih harus dikaji. Penelitian ini bertujuan untuk mengetahui pengaruh perendaman dan durasi perendaman dalam larutan madu terhadap rasio kelamin jantan benih ikan nila. Menggunakan larva berumur 7 hari hasil pemijahan semi-buatan dengan induksi hormon, penelitian ini dilakukan menggunakan 4 perlakuan (durasi perendaman) dengan 1 konsentrasi $(15 \mathrm{~mL} / \mathrm{L})$. Untuk mengetahui rasio kelamin jantan, analisa histologis dengan pewarnaan asetokarin dilakukan untuk mengamati gonad benih hasil perlakuan. Perendaman larva ikan nila pada larutan madu konsentrasi $15 \mathrm{~mL} / \mathrm{L}$ selama 20 jam mampu menghasilkan $80 \%$ benih berkelamin jantan. Sebagai kesimpulan, durasi perendaman berpengaruh terhadap rasio kelamin jantan yang dihasilkan dan perendaman selama 20 jam adalah durasi perendaman terbaik untuk larva ikan nila.
\end{abstract}

Kata kunci: chrisin, madu, maskulinisasi, monoseks, nila

Abstract: Farming monosex male tilapia has an important role in improving the production of Nile tilapia. Although synthetic hormone is commonly used to produce male monosex tilapia, this method poses a serious threat to food safety and consumer's health due to carcinogenic potential and bioaccumulation of the synthetic hormone in ecosystem. In contrast, honeybee is a natural product containing Chrysin, an aromatase inhibitor, which is known to cause masculinity in fish and can be used for masculinization. To date, however, the effect of honeybee on tilapia larvae's masculinization is yet to be studied. This research aimed to study the effect of immersion and its duration in honeybee'of Nile Tilapia's Larvae in honeybee's solution and length of immersion on male ratio. This research was conducted in quadruple consisting of three different times of immersion (duration of immersion) and one concentration $(15 \mathrm{~mL} / \mathrm{L})$. Using 7-day post hatched Nile tilapia larvae from semiartificial breeding, we determined male ratio based on histological analysis using acetocarmine stain. The result show that the Nile Tilapia's larvae treated at the concentration of $15 \mathrm{~mL} / \mathrm{L}$ of honeybee for 20 hours had the highest male ratio (80\%). To conclude, immersion in honeybee solution affected male ratio with 20 hours length of immersion resulting in the highest male ratio for tilapia's larvae.

Keyword: chrysin, honeybee, masculinization, monosex, nile tilapia 


\section{PENDAHULUAN}

Budidaya ikan monosex sangat tepat untuk spesies-spesies ekonomis penting dan memiliki karakteristik dimorfisme kelamin seperti laju pertumbuhan, warna dan untuk seleksi karakteristik berdasarkan jenis kelamin tertentu (Golan \& Sivan, 2014) seperti pada ikan nila. Ikan nila merupakan salah satu komoditas budidaya ekonomis penting dimana ikan jantan tumbuh lebih cepat daripada betina sehingga teknik monosex jantan cocok untuk meningkatkan produksi budidaya ikan nila (Sayed \& Moneeb 2015). Hingga sekarang, metode maskulinisasi ikan masih menggunakan hormon sintetik seperti 17 $\alpha$-metiltestosterone (Afprianinggrum et al., 2016; Rosmaidar et al., 2014). Padahal, meskipun efektif, senyawa-senyawa sintetik biasanya meninggalkan residu karsinogenik yang bukan saja tidak memenuhi syarat keamanan pangan tetapi juga membahayakan konsumen (Hoga et al., 2018).

Di pihak lain, madu merupakan bahan alami yang mengandung senyawa chrysin. Sejumlah peneliti telah melaporkan bahwa chrysin dapat menghambat sintesis dan kerja enzim aromatase yang berpengaruh terhadap proses steroidogenesis untuk pengarahan jenis kelamin jantan (Ciftci et al., 2010; Altawash et al., 2017). Beberapa penelitian yang menggunakan chrysin maupun aromatase inhibitor yang berasal dari bahan alami menyatakan bahwa teknik perendaman dapat menghasilkan benih berkelamin jantan dengan kisaran $60-70 \%$ (Ariyantio et al., 2010; Rosmaidar et al., 2014).

Meskipun demikian, keberhasilan senyawasenyawa aromatase inhibitor dari bahan alami dalam meningkatkan rasio maskulinisasi bergantung pada beberapa faktor diantaranya dosis madu, umur larva dan kondisi lingkungan (Ariyantio et al., 2010; Rosmaidar et al., 2014). Sementara beberapa peneliti lain melaporkan rentang rasio lebih besar mencapai (90-100\%) ketika mereka menggunakan 17- $\alpha$ Metiltestoteron (Singh et al., 2018; Srisakultiev \& Komonrat, 2013). Selisih perbandingan rasio yang besar antara penggunaan 17- $\alpha$-Metiltestosterone dan aromatase inhibitor dari bahan alami sangat beralasan, mengingat metil testoteron itu sudah berada dalam keadaan murni dan madu atau senyawa dari bahan alami masih belum berada dalam keadaan murni. Maka penambahan waktu perendaman kemungkinan dapat memberikan pengaruh terhadap rasio kelamin jantan pada teknik maskulinisasi dengan menggunakan larutan madu. Berdasarkan bukti-bukti ilmiah di atas, penelitian ini bertujuan untuk mengetahui (1) pengaruh durasi perendaman larva ikan nila dalam larutan madu terhadap rasio kelamin jantan dan (2) durasi perendaman terbaik terhadap rasio kelamin jantan.

\section{METODE PENELITIAN}

Penelitian ini dilakukan dalam beberapa tahapan dan pengujian. Untuk wadah induk digunakan 2 unit akuarium dengan ukuran 60x30×30 $\mathrm{cm}^{3}$ dengan volume 50 liter/akuarium. Untuk wadah perlakuan dan pemeliharaan larva, digunakan 12 unit wadah kaca dengan volume $3 \mathrm{~L}$ yang didistribusikan untuk setiap perlakuan dan ulangan. Indukan yang digunakan adalah indukan ikan nila (Oreochromis niloticus) dengan ukuran 250gr-300gr sebanyak 4 ekor dengan perbandingan 1:1 jantan dan betina. Indukan diaklimatisasi selama 7 hari pada lingkungan akuarium secara terpisah antara jantan dan betina. Selama masa aklimatisasi, indukan diberi pakan komersil MG-2 dua kali sehari secara at satiation. Pemijahan dilakukan dengan teknik pemijahan semibuatan menggunakan hormon Ovaprim.

Larva yang digunakan adalah larva hasil pemijahan berumur 7 hari setelah menetas (dph) sebanyak 180 ekor yang didistribusikan pada setiap perlakuan dan ulangan. Untuk pemeliharaan larva, tiga hari pertama setelah perlakuan larva diberi pakan larutan kuning telur dan selanjutnya diberi pakan cyst artemia dua kali sehari secara at satiation. Madu yang digunakan adalah madu lebah alami dengan dosis $15 \mathrm{ml} / \mathrm{l}$ (Odara et al., 2015). Perlakuan yang digunakan adalah waktu perendaman, menggunakan 4 perlakuan (5 jam, 10 jam, 15 jam dan 20 jam) dimana setiap perlakuan dilakukan $3 x$ ulangan. Setiap perlakuan dengan ulangannya menggunakan 15 ekor larva dengan volume air sebanyak 2 liter. Setelah perlakuan larva dipelihara selama 10 hari pada wadah dan volume air yang sama. Kualitas air dijaga dengan menggunakan aerasi dan mengganti air 2 hari sekali selama masa pemeliharaan. Selama masa perlakuan akan dilakukan pengukuran suhu dan $\mathrm{pH}$ setiap hari 
menggunakan $\mathrm{pH}$ meter secara digital yang sekaligus juga dapat mengukur suhu air.

Parameter uji yang digunakan dalam penelitian ini yaitu, persentase kelamin jantan dan sintasan hidup atau survival rate (SR). Persentase individu jantan dihitung dengan menggunakan rumus (Soesanti, 2015):

Benih jantan $(\%)=$ (jumlah benih jantan/jumlah benih) $\mathrm{x} 100$

Sedangkan pada perhitungan presentase sintasan hidup larva dapat dihitung dengan menggunakan rumus (Soesanti, 2015) :

$$
\mathrm{SR}=\frac{N t}{N 0} \times 100 \%
$$

Dimana:

$\mathrm{SR}=\operatorname{Sintasan}(\%)$

$\mathrm{N}_{\mathrm{t}} \quad=$ Jumlah larva pada akhir pemeliharaan

$\mathrm{N}_{0} \quad=$ Jumlah larva pada awal pemeliharaan

Untuk mengetahui jenis kelamin yang dihasilkan maka analisa histologi dilakukan pada gonad benih yang telah dipelihara. Analisa histologi menggunakan metode pewarnaan asetokarmin. Gonad yang digunakan untuk analisa histologi diperoleh dengan cara membedah benih ikan nila kemudian memisahkan gonadnya. Gonad yang diperoleh dicacah di atas kaca preparat, kemudian ditetesi dengan pewarna asetokarmin dan diamati di bawah mikroskop. Data yang diperoleh ditabulasi dalam bentuk rata-rata dan disajikan dalam bentuk histogram.

\section{HASIL DAN PEMBAHASAN}

Hasil pengujian memperlihatkan variasi pada rasio kelamin jantan berdasarkan perlakuan dengan kisaran 68,3\% dan 80\%. Terlihat pada Gambar 1 rasio kelamin jantan tertinggi terdapat pada kelompok perlakuan ke-4 (lama perendaman 20 jam) sebesar $80 \%$ sedangkan rasio kelamin jantan terrendah pada kelompok perlakuan ke-1 dan ke-2 (lama perendaman 5 jam dan 10 jam) sebesar 68,3\%.

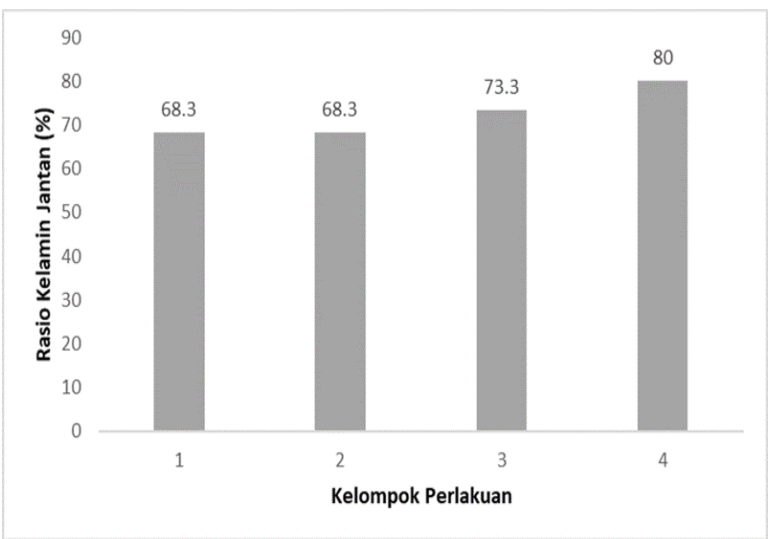

Gambar 1. Rasio kelamin jantan pada setiap kelompok perlakuan. Perlakuan $1=5$ jam; Perlakuan $2=10$ jam; Perlakuan 3 $=15$ jam; Perlakuan $4=20$ jam.

Hasil di atas diperoleh melalui falidasi jenis kelamin dengan pewarnaan asetokarmin pada gonad larva ikan nila yang diamati. Falidasi gonad larva ikan nila ini dapat dilihat pada Gambar 2 dan Gambar 3. Pada Gambar 2 dapat dilihat jaringan testis yang dengan sel-sel germa yang sedang berkembang sedangkan pada Gambar 3 dapat dilihat sel-sel folikel yang sedang berkembang.

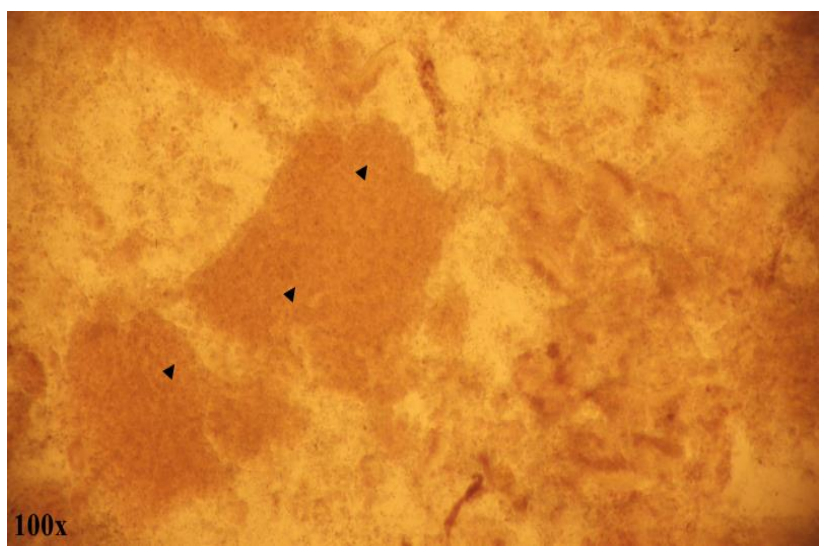

Gambar 2. Penampang histologis testis larva ikan nila; jaringan testis dengan sel-sel germa yang sedang berkembang (anak panah hitam). 


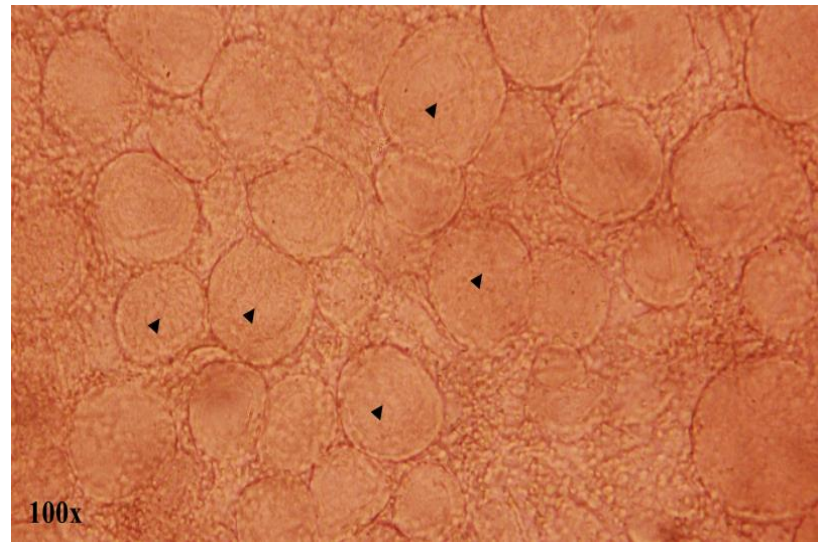

Gambar 3. Penampang histologis ovarium larva ikan nila; jaringan ovarium dengan sel-sel folikel yang sedang berkembang (anak panah hitam).

Data rasio kelamin jantan yang dihasilkan menunjukkan adanya keterkaitan antara lama perendaman dan rasio kelamin jantan. Dapat dilihat bahwa perlakuan dengan lama perendaman 20 jam memberikan nilai tertinggi dibandingkan dengan kelompok perlakuan yang lain. Sejalan dengan penelitian yang dilakukan oleh Srisakultiew \& Kamonrat (2013), yang menyatakan bahwa rasio kelamin jantan yang diperoleh dipengaruhi oleh lama waktu perendaman yang dilakukan, dimana lama waktu perendaman berkorelasi positif dengan rasio kelamin jantan yang dihasilkan. Dari hasil yang diperoleh juga dapat dilihat bahwa waktu perendaman 5 jam dan 10 jam memberikan rasio yang sama, kedua penulis menjelaskan bahwa hal ini berkaitan dengan kempuaan senyawa yang diberikan untuk mencapai organ target dan masa labil proses penentuan jenis kelamin.

Beberapa penelitian membuktikan bahwa perendaman larva ikan untuk teknik maskulinisasi akan memberikan hasil yang efektif apabila dilakukan selama masa labil penentuan jenis kelamin pada ikan dengan rasio kelamin jantan mencapai $90 \%$ (Ariyantio et al., 2010; Srisakultiew \& Kamonrat, 2013; Rosmaidar et al., 2014; Yustiati et al., 2018). Pada penelitian yang dilakukan, waktu perendaman terlama yang dilakukan adalah 20 jam dengan hasil sebesar $80 \%$. Penggunaan waktu perendaman ini bisa dikatakan tidak terlalu efektif untuk meningkatkan rasio kelamin jantan pada ikan nila bila dikaitkan dengan penjelasan di atas.

Hasil pengukuran kualitas air ( $\mathrm{pH}$ dan suhu) selama masa perlakuan terlihat pada Tabel 1 di bawah ini.

Tabel 1. Pengukuran Kualitas Air

\begin{tabular}{|c|l|l|}
\hline No & \multicolumn{1}{|c|}{ Parameter } & \multicolumn{1}{|c|}{ Hasil Pengukuran } \\
\hline 1. & $\mathrm{pH}$ & $6,5-7$ \\
\hline 2. & Suhu & $26-27^{\circ} \mathrm{C}$ \\
\hline
\end{tabular}

Hasil di atas memperlihatkan kisaran parameter kualitas air $\mathrm{pH}$ berada pada kisaran 6,5 - 7 dan suhu dengan kisaran $26-27{ }^{\circ} \mathrm{C}$ yang dapat dikatakan masih stabil dan menunjang kehidupan ikan nila. $\mathrm{pH}$ di perairan biasanya dipengaruhi oleh kandungan oksigen terlarut, jika oksigen terlaraut stabil maka pH juga akan stabil. Sejalan dengan hasil penelitian yang dilakukan oleh Azhari \& Tomasoa (2018) membudidayakan ikan nila kisaran $\mathrm{pH}$ yaitu 6 - 7, namun ikan nila mengalami pertumbuhan optimal pada kisaran $\mathrm{pH} 7-8$ (Wijayanti et al., 2019). Begitu juga dengan parameter suhu air menurut Mas'ud (2014) kisaran suhu dalam budidaya ikan nila yaitu $28-32{ }^{\circ} \mathrm{C}$ sedangkan Gupta \& Acosta (2004) dalam Azhari \& Tomasoa (2018) menyatakan bahwa kisaran suhu yang optimal untuk budidaya ikan nila yaitu $25-30{ }^{\circ} \mathrm{C}$.

\section{KESIMPULAN}

Dari penelitian yang dilakukan untuk menentukan rasio kelamin jantan pada larva ikan nila yang direndam dengan madu pada durasi perendaman berbeda, dapat ditarik beberapa kesimpulan: (1). Waktu perendaman memberikan pengaruh terhadap rasio kelamin jantan pada larva ikan nila yang direndam dengan madu. (2). Waktu perendaman terbaik pada teknik maskulinisasi menggunakan madu adalah selama 20 jam dengan rasio kelamin jantan sebesar $80 \%$. 


\section{DAFTAR RUJUKAN}

Afriyaningrum MD, Soeslistyowati DT, Alimuddin, Zairin. Jr M, Setiawan M, Herdiantho D. 2016. Maskulinisasi Ikan Nila Melalui Perendaman Larva Pada Suhu $36^{\circ} \mathrm{c}$ dan Kadar Residu 17a Metiltestosteron Dalam Tubuh Ikan. Omni-Akuatika. 12 (3): 106-113.

Altawash ASA, Shahneh AZ, Moravej H, Ansari M. 2017. Chrysin-Induced Sperm Parameters and Fatty Acid Profile Changes Improve Reproductive Performance of Roosters. Theriogenology, 104: 72-79.

Ariyanto D, Sumantadinata K, Sudrajat AO. 2010. Diferensiasi Kelamin Tiga Genotip Ikan Nila Yang Diberi Bahan Aromatase Inhibitor. Jurnal Ris Akuakultur, 5 (2): 166-174.

Azhari D \& Tomasoa, AM. 2018. Kajian Kualitas Air dan Pertumbuhan Ikan Nila (Oreochromis niloticus) yang Dibudidayakan dengan Sistem Akuaponik. Jurnal Akuatika Indonesia, 3(2): 84-90

Ciftci O, Ozdemir I, Aydin M, Beytur A. 2010. Beneficial Effects of Chrysin on the Reproductive System of Adult Male Rats. Andrologia, 44: 181-186.

Delvin RH, Nagahama Y. 2002. Sex Determination and Sex Differentiation in Fish: An Overview of Genetic, Physiological, and Environmetal Influences. Aquaculture 208: 191-364.

Deswira U, Sudrajat AO, Soelistyowati DT. 2015. Mekanisme Ahli Kelamin Ikan Nila Oreochromis niloticus (Linnaeus, 1795) Melalui Manipulasi Ekspresi Gen Aromatase. Jurnal Ikhtiologi Indonesia, 16 (1): 67-74.

Golan M, Sivan BL. 2014. Artificial Masculinization in Tilapia Involves Androgen Receptor Activation. General and Comparative Endocrinology. 207: 50-55.

Hoga CA, Almeida FL, Reyes FGR. 2018. A Review on Th Use of Hormone in Fish Farming. Analytical Methods for Determine Their Residues. Journal of Food. 16 (1): 679-691.

Kautsari N, Rahma S, Syafikri D. 2015. Pengaruh Perendaman Larva Dengan Berbagai Dosis Madu Sumbawa Terhadap Nisbah Jenis Kelamin Dan Pertumbuhan Ikan Nila (Orechromis niloticus) (Linnaeus, 1758). Jurnal Iktiologi Indonesia, 15 (2): 99-106.

Odara SS, Watung JC, Sinjal HJ. 2015. Maskulinisasi Larva Ikan Nila (Oreochromis niloticus) Melalui Penggunaan Madu Dengan Konsentrasi Berbeda. Jurnal Budidaya Perairan. 3 (2): 1-6.
Mas'ud F. 2014. Pengaruh Kualitas Air terhadap Pertumbuhan Ikan Nila (Oreochromis sp.) di Kolam Beton dan Terpal. Grouper Faperik, 5(1): 1-6

Rosmaidar, Winaruddin, Herlina M. 2014. Peningkatan Jumlah Nila (Oreochromis Niloticus) Jantan Melalui Penggunaan Hormon Metiltestosteron Alami. Jurnal Medikal Veterinaria. 8 (2): 128-131.

Sanchez WMC, Couturier GM, Marques TRE, Lopez LAD. 2002. Masculinization of Nile Tilapia Fry by Immersion in Trenbolone Acetate: Reuse of Hormone Solution and Effects of Temperature. Nineteenth Annual Technical Report. Pond Dynamics/Aquaculture CRSP, Oregon State University, Corvallis, Oregon. 35-38.

Sayed AEH, Moneeb RH. 2015. Hematological and Biochemical Characters of Monosex Tilapia (Orechromis niloticus Linnaeus, 1758) Cultivated Using Methyltestosterone. The journal of Basic \& Applied Zoology. 72 (5): 36-42.

Singh E, Saini VP, Sharma OP. 2018. Orally Administered 17 a methyl testosterone at Different Doses on The Sex Reversal of The Red Tilapia (Oreochromis niloticus). International Journal of Fisheries and Aquatic Studies. 6 (3): 103-105.

Soelistyowati DT, Sudrajat AO, Arfah H. 2010. Maskulinisasi Pada Ikan Nila Merah (Oreochromis sp.) Menggunakan Bahan Alami Resin Lebah Melalui Pakan Buatan. Jurnal Akuakultur Indonesia. 9 (2): 178-183.

Soesanti S. 2015. Maskulinisasi Larva Ikan Nila (Oreochromis niloticus) Melalui Penggunaan Madu Dengan Konsentrasi Berbeda. Jurnal Budidaya Perairan, 3 (2): 1-6.

Srisakultiew P, Komonrat W. 2013. Immersion of $17 \alpha-$ Methyltestosterone Dose and Duration on Tilapia Masculinization. Journal of Fisheries Science. 7 (4): 302-308.

Yustiati A, Bangkit I, Zidni I. 2018. Masculinization of Nile Tilapia (Oreochromis niloticus) Using Extract of Bull Testes. IOP Conf. Ser.: Earth Environ. Sci. 139: 1-9

Wijayanti M, Khotimah H, Sasanti AD, Dwinanti SH, Rarassari MA. 2019. Pemeliharaan Ikan Nila (Oreochromis niloticus) dengan Sistem Akuaponik di Desa Karang Endah, Kecamatan Gelubang, Kabupaten Muara Enim Sumatra Selatana. Journal of Aquaculture and Fish Health, 8(3): 139-148. 